\title{
SIKAP MAHASISWA BAHASA INGGRIS TERHADAP PENGGUNAAN TEKNIK TEAM GAME TOURNAMENT (TGT) PADA MATA KULIAH READING COMPREHENSION III
}

\author{
Hendra Eka Putra \\ Program Studi Tadris Bahasa Inggris, Jurusan Tarbiyah STAIN Batusangkar \\ Korespondensi: Jorong Balai Batu Lima Kaum, Batusangkar, Sumatera Barat \\ E-mail: hendraekaputra76@gmail.com
}

\begin{abstract}
This research was inspired because of the researcher previous research. Based on the result of the research, he found that there was a contradiction between the students' enthusiastic and their score after appying Team Game Tournament (TGT) technique. They had highly positive to the use of the technique, but they had low score after doing the reading test. It was the reason why the researcher tried to reresearch about the trueness whether the technique was still possible to be used at Reading Comprehension classroom or not. This research was descriptive quantitative one. Respondent of the research was the third semester students of English department of Tarbiyah Faculty of STAIN Batusangkar registered in 2013/2014 academic year. Data of the research was collected by giving questionnaire and observation note. After analyzing the data of the research, it was known that the students' attitude toward the use of Team Game Tournament (TGT)technique at Reading Comprehension III classroom was positive in which there were 16 students $(42,1 \%)$ had positif attitude toward the use of the technkique.
\end{abstract}

Kata kunci: Sikap Mahasiswa, Team Game Tournament

\section{PENDAHULUAN}

$\mathrm{K}$ esuksesan dalam belajar ditentukan oleh banyak faktor. Menurut nyak faktor yang mempengaruhi prestasi balajar: internal dan eksternal. Kondisi fisik dan psikologi seperti kesehatan, intelektualitas, motivasi, sikap, ketertarikan, dan perilaku merupakan contoh dari faktor yang berasal dari dalam diri. Sementara, pola asuh dan ekonomi keluarga, metode pengajaran oleh guru/ dosen di sekolah/kampus, kurikulum, dan yang tidak kalah berpengaruh seperti lingkungan peserta didik adalah faktor yang berasal dari luar diri.

Merujuk fator-faktor tersebut di atas, peneliti tertarik untuk mengutip sebuah teori oleh Harmer (2003: 66) yang mengatakan bahwa: "there are some ways to teach English for students." Ia manegaskan bahwa pendidik dapat memperkenalkan bahasa dengan memberikan kesempatan kepada pembelajar untuk melihat dan mendengar bahasa sebelum mereka diminta untuk mengucapkan secara lansung. Oleh karena itu menurutnya pendidik dapat menggunakan berbagai strategi mengajar kepada peserta didik untuk meningkatkan kemampuan bahasa mereka.

Terkait dengan penelitian sebelumnya, peneliti telah mencoba menggunakan sebuah teknik pengajaran yaitu Team Game Tournament (TGT) dalam pengajaran membaca pada mata kuliah Reaing Comprehension IV, namun upaya peningkatan kemampuan bahasa maha- 
siswa terutama dalam pemaham membaca belum berhasil sebagaimana yang diharapkan. Ini ditunjukkan dari tes pemahaman membaca yang telah dilaksanakan kepada mahasiswa semester IV C TA. 2012/2013 Program Studi Tadris Bahasa Inggris Jurusan Tarbiyah STAIN Batusangkar, dimana tidak terjadi peningkatan prestasi belajar mereka yang ditunjukan dari perbandingan rata-rata pre dan post-test mereka.

Ini bertolak belakang sekali dengan keantusiasan mereka sewaktu teknik Team Game Tournament (TGT) ini digunakan didalam kelas. Keantusiasan mereka ini terlihat dari keaktifan mereka dalam kelompok mereka masing-masing. Sewaktu tantangan-tantangan berupa bacaan yang diberikan kepada mereka untuk dipahami, hampir semua mahasiswa fokus dengan bacaan tersebut. Dan ketika pemberian pertanyaan-pertanyaan melalui permainan-permainan yang telah dipersiapkan untuk mereka, para mahasiswa tersebut saling berebut untuk menjawab pertanyaan tersebut.

Melihat realita seperti itu, timbul pertanyaan dari diri peneliti sendiri apakah teknik yang telah peneliti gunakan yang bermasalah atau ada faktor lainnya yang menyebabkan terjadinya hal yang demikian itu. Oleh karena itu, peneliti tertarik untuk mencoba kembali pada mahasiswa bahasa Inggris semester III C TA. 2014/2015 yang sedang mengambil mata kuliah Reading Comprehension III dan sekaligus melihat sikap mahasiswa terhadap penggunaan Teknik Team Game Tournament (TGT) ini. Alasan lainnya kenapa peneliti ingin meneliti ini adalah peneliti menganggap teknik ini cukup menarik minat mahasiswa untuk membaca melalui tantangan-tantangan melalui permainan kendatipun hasil yang telah diperoleh belumlah berhasil baik.

\section{METODE PENELITIAN}

Penelitian ini adalah Penelitian deskriptif quantitatif yang menggambarkan bagaimana sikap mahasiswa bahasa Inggris terhadap penggunaan Teknik Team Game Tournament (TGT) pada mata kuliah Reading Comprehension IV. Gay (2000: 11) menyatakan bahwa: "descriptive research involvels collecting data in order to answer questions about the current status of the subject or topic of study." Maksudnya adalah penelitian deskriptif dilakukakan guna menggali informasi tentang rasa suka (preferences), sikap (attitude), latihan-latihan (practices), atau ketertarikan (interest) terhadap sekelompok orang.

Responden penelian ini adalah mahasiswa semester III/C TA. Ganjil 2014/15 Program Studi Tadris Bahasa Inggris Jurusan Tarbiyah STAIN Batusangkar yang berjumlah 38 orang. Adapun dipilihnya responden tersebut adalah karena mereka adalah mahasiswa yang peneliti ampu pada mata kuliah tersebut.

Dalam menyelesaikan penalitian ini, peneliti telah mengikuti beberapa langkah-langkah penalitian. Adapun uraiannya adalah sebagai berikut:

1. Persiapan

a. Menemukan masalah penalitian

b. Mengumpulkan teori-teori, sumber-sumber dan kajian kepustakaan yang relevan dengan penelitian

c. Menulis proposal penelitian

d. Mengikuti seminar proposal penelitian

2. Tindakan

a. Merancang jadwal penelitian dan mempersiapkan segala sesuatu yang berhubungan dengan angket yang akan diberikan.

b. Memberikan angket ke partisipan.

c. Mengumpulkan angket

3. Penutup

a. Melakukan analisa data

b. Menginterpretasikan data 
c. Mengambil kesimpulan dari proses analisa data

Adapun instrumen penelitian ini adalah angket (questionnaire) dan lembaran observasi (observation note). Pemberian nilai skor angket dikutip dari teori Gay (2000: 156) yang menyatakan bahwa: "a Likert scale ask participant to respond a series of statement. They are strongly agree (SA), agree (A), undecided $(U)$, disagree $(D)$, or strongly disagree (SD) with each statement." Skor diberikan berdasarkan jenis pernyataan. Jika pernyataan positif, skor diurut dari $\mathrm{SA}=5, \mathrm{~A}=4, \mathrm{U}=3, \mathrm{D}=2$ dan $\mathrm{SD}=1$ dan atau sebaliknya untuk yang pernyataan negatif. Penjelasan terkait pemberian skor dapat dilihat pada tabel berikut ini.

Tabel 2.

Skor Pengelompokan Pernyataan Angket

\begin{tabular}{ccc}
\hline & \multicolumn{2}{c}{ Pernyataan } \\
\cline { 2 - 3 } Pengelompokan & Positif & Negatif \\
\hline Sangat Setuju & 5 & 1 \\
\hline Setuju & 4 & 2 \\
\hline Ragu-Ragu & 3 & 3 \\
\hline Disagree & 2 & 5 \\
\hline Sangat Tidak Setuju & 1 &
\end{tabular}

Dalam pengumpulan data (angket), peneliti sengaja membuatnya (angket) dalam bahasa Indonesia untuk mempermudah responden memahami angket tersebut. Contoh angket dapat dilihat pada tabel berikut.

Tabel 3.

Contoh Pernyataan Angket Penelitian

\begin{tabular}{cllllll}
\hline No & \multicolumn{1}{c}{ Item Pertanyaan } & SS & S & RR & TS & STS \\
\hline 1 & Teknik Team Game Tournament & & & & & \\
yang digunakan oleh dosen & & & & & \\
& Reading Comprehension III & & & & \\
memberikan banyak peluang & & & & \\
kepada saya untuk bisa & & & & \\
& mengatasi masalah-masalah & & & & \\
& yang saya hadapi dalam & & & & \\
memahami bacaan. & & & & \\
\hline
\end{tabular}

Kemudian peneliti menggunakan enam langkah pembuatan angket yang dianjurkan oleh Suharsimi (1996: 135) sebagai berikut:

1. Mengidentifikasi variabel permasalahan penelitian

2. Merinci variabel kedalam sub variabel

3. Menemukan indikator setiap permasalahan
4. Membuat rentang deskripsi dari setiap indikator

5. Membuat formulasi deskripsi ke dalam pernyataan di dalam angket

6. Melengkapi angket dengan memberikan perintak dan petunjuk pengisian angket.

Selajuntnya, peneliti akan menemui validator yang akan mengkoreksi angket tersebut sebelum diberikan 
kepada partisipan penelitian ini. Setelah angket di kumpulkan dan di skor, peneliti melakukan wawancara terhadap mahasiswa tersebut untuk melihat kejujuran mereka.

Untuk mengumpulkan data, peneliti mengikuti beberapa langkah yaitu:

1. Mengecek angket mahasiswa.

2. Memberikan kode pada angket yang sudah diisi mahasiswa

3. Mentabulasi data

4. Memberikan nilai

5. Mencari persentase data

Untuk menganalisa data, peneliti menggunakan rumus yang disarankan oleh Anas (2005: 43) berikut ini:

$$
\mathrm{P}=f x \text { 100\% }
$$

\section{$\mathrm{N}$}

$$
\begin{aligned}
& \text { Dimana : } \mathrm{P}=\text { Persentase } \\
& f=\text { Frekuensi skor } \\
& \mathrm{N}=\text { Jumlah }
\end{aligned}
$$

6. Menginterpretasikan data

Untuk menginterprestasikan angket, peneliti mengelompokkan sikap mahasiswa terhadap penggunaan teknik Team Game Tournament (TGT) berdasarkan beberapa kategori yang disarankan oleh Anas (2007: 161). Pengkategorian tersebut dapat dilihat pada tabel berikut ini.

Tabel 4.

Pengelompokkan Sikap Mahasiswa terhadap Penggunaan Teknik Team Game Tournament (TGT) pada Mata Kuliah Reading Comprehension III

\begin{tabular}{lc}
\hline \multicolumn{1}{c}{ Jumlah Rata-Rata } & Penjelasan \\
\hline$(M+1,5$ SD $)$ & Sangat Positif \\
\hline$(M+0,5$ SD $)-(M+1,5$ SD $)$ & Positif \\
\hline$(M-0,5$ SD $)-(M+0,5$ SD $)$ & Biasa-Biasa Saja \\
\hline$(M-1,5$ SD $)-(M-0,5$ SD $)$ & Negatif \\
\hline$(M-1,5$ SD $)$ & Sangat Negatif \\
\hline
\end{tabular}

7. Mencatat frekwensi dan persentase dalam tabel

8. Membuat kesimpulan

\section{PEMBAHASAN}

\section{Kajian Teori yang Relevan}

\section{Defenisi Sikap}

Ada beberapa definisi sikap menurut para ahli. Pertama, Azjen in Alex (2003: 355) menegaskan bahwa: "attitude is disposition to respond favorably or unfavorably to an object, person, institution or event." Ini dapat diartikan bahwa sikap merupakan keyakinan, perasaan atau opini terhadap sebuah objek, orang, institusi ataupun kejadian.
Kemudian, Ngalim (2007: 140) mendefinisikan sikap sebagai cara merespon terhadap sebuah tindakan. Ia juga mengatakan bahwa sikap meliputi beberapa pengetahuan tentang situasi. Namun, masih menurutnya, aspek penting dari sikap ditemukan pada fakta dimana perasaan atau emosi dialami melalui pengalaman, sementara ada juga yang dikondisikan.

Selanjutnya, Djaali (2007: 114) mengatakan bahwa sikap merupakan sebuah aksi yang ingin dilakukan terhadap objek. Senada, Sarlito (2010: 200) menyatakan bahwa sikap adalah sebuah perilaku yang menunjukan suka dan tidak suka atau tidak memihak dari seseorang terhadap sesuatu hal. Kedua teori ini didukung oleh Muhibbin (2007: 120) yang mengatakan bahwa sikap 
adalah mental tendensi. Atau dengan kata lain sikap dapat diartikan sebagai tujuan seseorang melakukan sesuatu hal dengan cara tertentu.

Sebagai kesimpulan, sikap dapat diartikan sebagai sebuah keinginan untuk melalukan atau menanggapi sesuatu. Sikap bisa berupa hal yang positif seperti rasa suka atau bisa juga berupa hal yang negatif seperti rasa benci seseorang terhadap sesuatu.

\section{Komponen Sikap}

Ada beberapa komponen dari sikap yang dinyatakan oleh para ahli. Pertama, Alex (2003: 359) mengatakan bahwa ada tiga komponen sikap yaitu kognitif, affektif dan behavior. Kognitif merupakan komponen yang merepresentasikan keyakinan seseorang. Sememntara, affektif berhubungan dengan askpek emosional. Dan yang terakhir, behavior, merupakan penentuan sikap dalam mengambil tindakan.

Mann in Alex (2003: 361) mengatakan bahwa: "cognitive includes perception, belief, and stereotype that should be had by individual about something." Kata Mann, komponen ini biasanya disebut juga dengan opini (opinion). Komponen affektif merupakan perasaan seseorang terhadap objek dan melibatkan emosi. Komponen ini dapat mengubah perilaku yang disebabkan oleh berbagai pengaruh. Dan, komponen behavior mencakup keinginan untuk bertindak terhadap sesuatu.

Kemudian, Hollander (1981: 88) menyatakan bahwa: "there are three major of attitude: the cognitive component of belief-disbelief, the affective component of like-dislike, and the action componennt of readiness to behave in line with attitude." Komponen kognitif merupakan apa yang sudah dipelajari oleh seseorang yang berkaitan dengan apa yang dipercayai oleh seseorang tentang kebenaran terhadap sesuatu. Sedangkan, komponen affektif berkaiatan dengan emosi tentang rasa atau tidak suka. Sementara, komponen aksi berhubungan dengan kesiapan untuk merespon sesuatu. Ini didukung oleh Fieldman (1996: 605) yang menyatakan bahwa: "the attitude consists of three components involving: cognitive that refers to belief, affective that refers to positive and negative emotion, and behaviour that refers to intention to act which is relevant with the attitude."

Terakhir, Bimo (2003: 111) menyatakan bahwa ada tiga komponen sikap. Ketiga komponen itu adalah komponen kognitif atau perceptual, komponen affektif dan komponen Konatif (Conative). Komponen kognitif berhubungan dengan pengetahuan, opini, keyakinan, atau bisa dikatakan segala sesuatu yang berhubungan dengan bagaimana persepsi seseorang terkait sikapnya terhadap objek. Komponen affektif atau emotional berkaitan dengan bahagia (positif) atau tidak bahagia (negatif) dan senang (favor) atau tidak senang (unfavor) terhadap sesuatu objek. Komponen konatif atau behaviour atau action berkaitan dengan tindakan yang ingin dilakukan tethadap objek tertentu.

Dirujuk kepada teori-teori yang tersebut diatas, maka dapat disimpulkan bahwa para ahli pada prinsipnya setuju mengatakan bahwa ada tiga komponen dari sikap. Yang membedakannya adalah ada dua orang ahli yang memiliki istilah berbeda terhadap komponenyang ketiga yaitu Holander menggunakan istilah action dan Bimo menggunakan istilah Conative untuk istilah Behaviour yang digunakan ahli lainnya. Untuk lebih rincinya, teori para ahli ini dapat dilihat perbandingannya pada tabel 1 berikut ini. 
Tabel 1.

Klasifikasi Sikap Menurut Ahli

\begin{tabular}{|c|c|c|c|c|}
\hline Alex & Mann & Holander & Fieldman & Bimo \\
\hline $\begin{array}{l}\text { Cognitive } \\
\text { (Belief) }\end{array}$ & $\begin{array}{l}\text { Cognitive } \\
\text { (Perception, } \\
\text { Belief, and } \\
\text { Stereotype) }\end{array}$ & $\begin{array}{l}\text { Cognitive } \\
\text { (Belief and } \\
\text { disbelief) }\end{array}$ & $\begin{array}{l}\text { Cognitive } \\
\text { (Belief and } \\
\text { disbelief) }\end{array}$ & $\begin{array}{l}\text { Cognitive } \\
\text { (Perceptual) }\end{array}$ \\
\hline $\begin{array}{l}\text { Affective } \\
\text { (Emotional } \\
\text { and Feeling) }\end{array}$ & $\begin{array}{l}\text { Affective } \\
\text { (Feeling and } \\
\text { Emotion) }\end{array}$ & $\begin{array}{l}\text { Affective } \\
\text { (Like and } \\
\text { Dislike) }\end{array}$ & $\begin{array}{l}\text { Affective } \\
\text { (Positive } \\
\text { Negative } \\
\text { Emotion) }\end{array}$ & $\begin{array}{l}\text { Affective } \\
\text { (Emotional) }\end{array}$ \\
\hline $\begin{array}{l}\text { Behaiour } \\
\text { (Predisposition } \\
\text { to Act) }\end{array}$ & $\begin{array}{l}\text { Behaviour } \\
\text { (Tendency to } \\
\text { Act) }\end{array}$ & $\begin{array}{l}\text { Action } \\
\text { (Readiness to } \\
\text { Response) }\end{array}$ & $\begin{array}{l}\text { Behaviour } \\
\text { (Intention } \\
\text { Act) }\end{array}$ & $\begin{array}{l}\text { Conative } \\
\text { (Action) }\end{array}$ \\
\hline
\end{tabular}

\section{Karakteristik Sikap}

Sikap dipandang sebagai sesuatu yang berbeda dari aspek lainnya seperti halnya kebiasaan (habit) dan pengetahuan (knowledge). Disini peneliti mengutip sebuah teori oleh Sarlito didalam Hendra (2012: 24) yang menyatakan bahwa ada beberapa karakteristik sikap. Karektiristik sikap tersebut adalah sebagai berikut:

1. Didalam sikap terdapat hubungan antara subyek dan obyek. Tidak akan adak sikap jika tidak ada obyek. Obyek tersebut dapat berupa sesuatu, orang, sekelompok orang, nilai sosial, pandangan hidup, hukum, institusi sosial dan lain sebagainya.

2. Sikap tidak dibawa sewaktu lahir tapi dipelajari dan terbentuk lewat pengalaman.

3. Karena dipelajari, apa yang dipelajari tersebut bisa berubah-ubah sesuai dengan situasi lingkungab yang muncul disekitar individu tertentu dalam waktu yang berbeda-beda pula.

4. Sikap tidak akan hilang meskipun kebutuhan telah dipenuhi. Inilah hal yang membedakan sikap dengan motivasi (Motivation).

5. Sikap itu jenisnya tidak hanya satu tetapi beragam sesuai dengan jumlah obyek yang dapat menjadi pusat perhatian sekelompok orang.

\section{Indikator Baik dan Tidak Baiknya Sebuah Sikap}

Menurut Wil and Elwood (2010: 18), positive attitude can be seen from the list below:

1. See more opportunities and more likely spot problem in time to avoid major consequences.

2. More likely to work to higher standard of quality, safety, and productivity.

3. Always looking out for other people.

4. More desirable to work with-and the work is more enjoyable.

5. More likely to be promoted to more responsible jobs; they are more likely to move up and forward.

Sementara, Asemota didalam Hendra (2012: 26) menyatakan bahwa: "the sign for the great attitude are:

1. Belief in self: when people believe in themselves, thay are free to focus on improving themselves and reaching their point.

2. Willingness to see the best in other: this is important because if people treat other people positively, they tend to treat them in the same way.

3. Ability to see opportunity everywhere: opportunies are not based on luck or 
position. People are result of right attitude; opportunities existh when they find it.

4. Focusing on solution: positive people maintain a solution mindset, seeing a solution in every problem and possibility in every impossibility.

5. Desisre to give: people are rarely negative people. Giving is the highest level of living. The more they give, the better their attitude.

6. Persistence: when people believe everything turns out for the best they do not mind a little discomfort.

7. Responsibility for people lives: a successful where people understand that nothing positive happens until they are willing to stepward and take full responsibility for their thoughts and actions. They can look themselve honestly, asses their strength and weakness and begin to change.

Pada sisi lain, tidak baiknya sebuah sikap dapat dilihat dalam teori Joe (2011) dimana ia mengatakan bahwa: "angry, negative body language, defensive, confronting others, words they use, cannot admit mistakes, will not forgive, lealously, critical of everything and everyone, problem oriented, and hostile to happiness are the examples of bad attitude."

\section{Faktor yang Mempengaruhi Sikap}

Ada banyak faktor yang mempengaruhi sikap menurut ahli. Pertama, Alex (2003: 363) menyatakan bahwa ada beberapa faktor yang mempengaruhi sikap seseorang. Yang pertama adalah akumulasi (accumulation). Maksudnya adalah interaksi dapat saja terjadi ketika seseorang memiliki sikap yang sama terhadap sesuatu. Yang kedua adalah observasi (observation). Observasi terhadap sikap yang berbeda-beda membuat seseorang dapat menentukan posisi mendukung atau tidak mendukung terhadap sebuah penomena. Yang ketiga adalah pengalaman (experience). Yang keempat adalah hasil meniru (imitation reult). Faktor yang keempat ini maksudnya adalah ada sebuah hasil dari aksi meniru terhadap sikap lainnya terkait dengan kondisi kewaspadaan atau ketidakwaspadaan.

\section{Teknik-Teknik Pengajaran Pemaham- an Membaca}

Pemahaman membaca dapat diajarkan melalui sejumlah teknik. Salah satunya adalah Cooperative Learning. Wikipedia (2013: 1) mengatakan bahwa: "Cooperative learning is an approach to orginizing classroom activities into academic and social learning experiences. It differ from group work, and it has been described as "structuring positive interdependence". Maksudnya adalah maha/siswa harus mengerjakan tugasnya dalam kelompok untuk melengkapi tugas-tugas tersebut secara kolektif sesuai denagan tujuan akademik.

Sementara, Teed (2013: 1) menyatakan bahwa:

"cooperative learning can be contrasted with what it is not. Cooperation is not having students sit side-by-side at the same table to talk with each other as they do their individual assignments. Cooperation is not assigning a report to a group of students where one student does all the work and the others put their names on the product as well."

Kemudian, Slavin in Jacobs (1997: 2), ada beberapa jenis dari cooperative learning yaitu: Students Team Learning (STL), Students Team Achievement Division (STAD), Team Game Tournament (TGT), Jigsaw, Cooperative Integrated Reading and Comprehension (CIRC), and Team Accelerated Instruction (TAI).

Dari teori di atas dapat dikatakan bahawa seorang dosen dapat memilih cooperative learning sebagai solusi permasalahan mereka dalam kelas. Dan ada banyak pilihan teknik yang dapat di- 
gunakan seperti yang disebutkan di atas. Oleh karenanya, dosen dapat memilih salah satu teknik tersebut sesuai dengan tujuan pengajaran mereka.

\section{Defini Team Game Tournament (TGT)}

Peneliti mengutip teori definisi oleh Slavin (2008: 2) dimana ia mengatakan bahwa pembelajaran kooperatif tipe TGT adalah salah satu tipe pembelajaran kooperatif yang mudah diterapkan, melibatkan aktivitas seluruh peserta didik tanpa harus ada perbedaan status, melibatkan peran mereka sebagai tutor sebaya dan mengandung unsur permainan dan penguatan (reinforcement). Aktivitas belajar dengan permainan yang dirancang dalam pembelajaran kooperatif tipe TGT memungkinkan peserta didik dapat belajar lebih rileks di samping menumbuhkan tanggung jawab, kerja sama, persaingan sehat dan keterlibatan belajar.

Dalam model ini, peserta didik dibagi dalam tim belajar yang terdiri atas empat sampai lima orang yang berbedabeda tingkat kemampuan dan jenis kelaminnya. Pendidik menyampaikan pelajaran, lalu peserta didik bekerja dalam tim mereka untuk memastikan bahwa semua anggota tim telah menguasai pelajaran. Selanjutnya diadakan turnamen, di mana peserta didik memainkan game akademik dengan anggota tim lain untuk menyumbangkan poin bagi skor timnya. Untuk penjelasan lebih lanjut tentang bagaimana mengaplikasikan teknik ini di dalam kelas dapat dilihat pada bagian langkah-langkah penggunaan teknik Team Game Tournament (TGT) di dalam kelas.

\section{Manfaat Penggunaan Teknik Team Game Tournament (TGT)}

Ada beberapa manfaat penggunaan teknik Team Game Tournament (TGT) menurut ahli. Slavin (2008: 3) menyatakan bahawa ada beberapa manfaat penggunaan teknik Team Game
Tournament di dalam kelas. Adapun manfaat penggunaan teknik tersebut adalah sebagai berikut:

1. Membuat pembelajar lebih aktif dalam belajar

2. Akan lebih menguasai materi yang diberikan

3. Dapat saling meningkatkan keahlian berbahasa

4. Proses belajar menjadi lebih menarik

5. Dapat meningkatkan qualitas mengajar.

Dari teori diatas dapat ditarik kesimpulan bahwa ada lima manfaat penggunaan teknik TGT dalam kelas. Teknik tersebut bisa digunakan oleh pendidik (guru atau dosen) dan peserta didik (siswa atau mahasiswa) untuk meningkatkan keahlian mereka sesuai dengan tujuannya masing-masing.

Langkah-Langkah Penggunaan Teknik Team Game Tournament (TGT) di dalam Kelas

Ada beberapa langkah-langkah penggunaan teknik Team Game Tournament (TGT) di dalam kelas. Menurut Slavin (2008), pembelajaran kooperatif tipe TGT terdiri dari 5 komponen utama, yaitu: presentasi di kelas, tim (kelompok), game (permainan), turnamen (pertandingan), dan rekognisi tim (perhargaan kelompok). Prosedur pelaksanaan TGT dimulai dari aktivitas pendidik dalam menyampaikan pelajaran, kemudian peserta didik bekerja dalam tim mereka untuk memastikan bahwa semua anggota tim telah menguasai pelajaran. Selanjutnya diadakan turnamen, di mana peserta didik memainkan game akademik dengan anggota tim lain untuk menyumbangkan poin bagi skor timnya. Adapun langkahlangkah konkrit pembelajaran kooperatif tipe TGT yang terdiri dari 5 langkah pembelajaran adalah sebagai berikut:

1. Class-Presentation

(Penyajian/Presentasi kelas) 
Pada tahapan ini, pendidik menyampaikan materi sebagaimana biasanya dan meminta peserta didik untuk memperhatikan dan memahami materi yang disampaikan pendidik. Ini dilakukan agar mereka bekerja lebih baik pada saat kerja kelompok dan pada saat game, karena skor game akan menentukan skor kelompok.

2. Team (Kelompok)

Pendidik kemudian membentuk kelompok yang terdiri dari 4 sampai 6 orang peserta didik yang anggotanya memiliki kemampuan yang bervariasi agar peserta didik belajar bersama dengan anggota kelompoknya untuk menyelesaikan tugas dan soal yang diberikan. Pendidik sebagai fasilitator mengarahkan peserta didik ketika mengalami kesulitan dalam penyelesaian tugas, serta memandu berfungsinya kelompok belajar.

3. Game (permainan)

Game terdiri dari pertanyaan-pertanyaan yang dirancang untuk menguji pengetahuan yang didapat peserta didik dari penyajian kelas dan belajar kelompok. Kebanyakan Game terdiri dari pertanyaan-pertanyaan sederhana bernomor. Pada tahapan ini, ada beberapa langkah yang harus diikuti yaitu:

a. Peserta didik memilih kartu bernomor yang memuat satu pertanyaan, kemudian kelompok yang berperan sebagai pemain mencoba menjawab pertanyaan yang sesuai dengan nomor itu.

b. Setelah pembaca memberikan jawaban, peserta didik disebelah kiri (penantang pertama) mempunyai kesempatan untuk menantang (memberi jawaban beda) atau lewat.

c. Jika penantang pertama lewat dan penantang kedua mempunyai jawaban berbeda maka penantang kedua boleh memberi tantangan. d. Jika semua peserta didik telah menjawab, menantang atau lewat penantang kedua (sebelah kanan pembaca) mencocokkan jawabannya pada kunci jawaban yang sesuai dan membacanya keraskeras. Pemain yang menjawab benar dapat menyimpan kartu tersebut.

e. Dan jika penantang pertama dan kedua salah dalam memberikan jawaban maka mereka mendapat hukuman yaitu harus mengembalikan kartu yang dimenangkan sebelumnya pada paknya.

f. Jika tidak ada yang menjawab benar, maka kartu dikembalikan pada paknya.

g. Untuk babak berikutnya semua pindah satu posisi ke kiri, dan penantang pertama giliran menjadi pembaca, penantang kedua menjadi penantang pertama dan pembaca menjadi penantang kedua.

h. Permainan berjalan terus sampai waktu yang ditentukan habis atau kartunya habis.

i. Ketika permainan berakhir, pemain mencatat jumlah kartu yang dimenangkan pada lembar pencatat skor.

4. Tournament (pertandingan/kompetisi) Turnamen dilaksanakan setelah pendidik melakukan presentasi kelas (berakhirnya sebuah pokok bahasan) dan kelompok sudah mengerjakan lembar kerja. Ada beberapa hal yang harus diperhatikan sewaktu melakukan turnamen yaitu:

a. Pada turnamen pertama, pendidik membagi peserta didik kedalam beberapa meja turnamen dengan kemampuan serupa yang mewakili tiap timnya. Kompetisi ini merupakan sistem penilaian kemampuan perorangan dalam STAD. Kompetisi ini juga memungkinkan bagi peserta didik dari semua level di penampilan sebelumnya untuk me- 
maksimalkan nilai kelompok mereka menjadi terbaik. Alur penempatan peserta turnamen menurut Slavin (1995: 86) dapat dilihat pada diagram pada halaman berikut ini.

b. Peserta didik masing-masing kelompok dari tingkat akademik tertinggi sampai tingkat terendah dikelompokkan bersama peserta didik dari kelompok lain yang mempunyai tingkat akademik sama untuk membentuk satu kelompok turnamen yang homogen.

c. Peserta didik dari masing-masing kelompok bertanding untuk me- nyumbangkan poin tertinggi bagi kelompoknya.

d. Dalam turnamen, peserta didik yang memiliki kemampuan akademik sedang atau rendah dapat menjadi peserta didik yang mendapat poin tertinggi dalam kelompok turnamennya.

e. Poin dari perolehan setiap anggota kelompok diakumulasikan dalam poin kelompok.

f. Turnamen diselenggarakan akhir minggu, setelah pendidik membuat presentasi kelas dan kelompokkelompok mempraktekkan tugastugasnya.

\section{Diagram: \\ Alur Penempatan Peserta Turnamen}

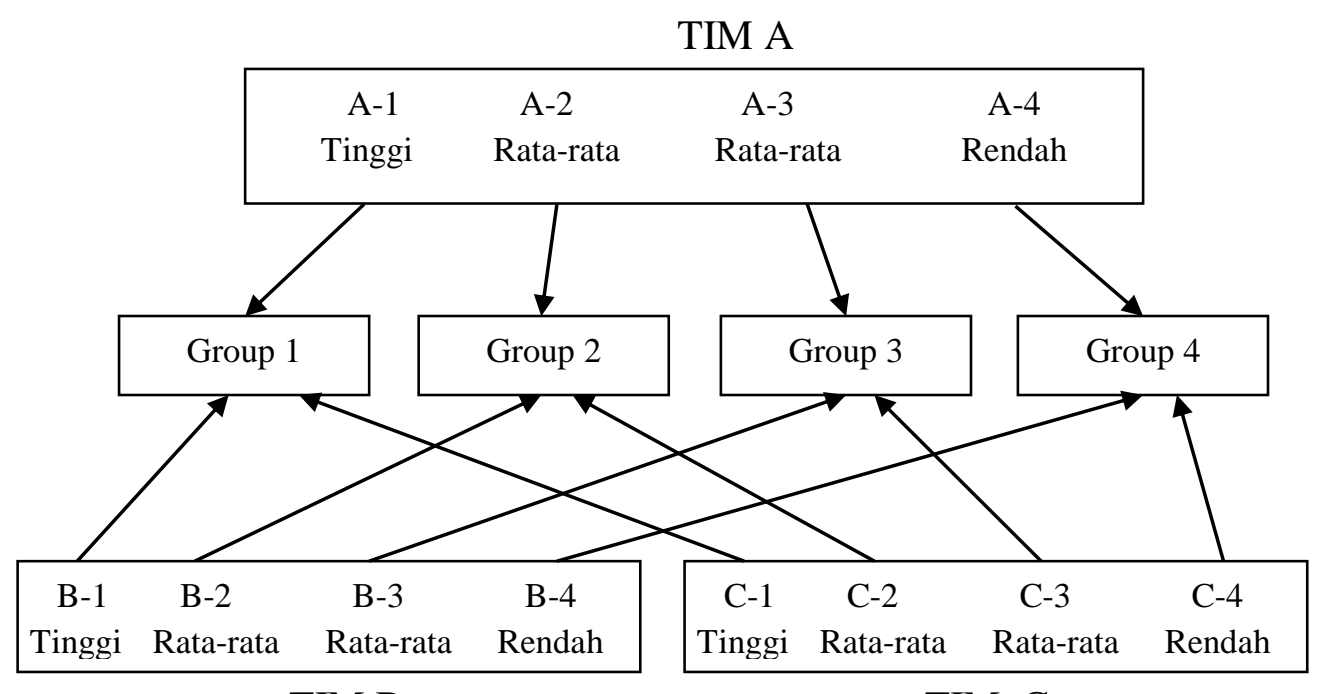

TIM B

TIM C

5. Team -Recognize (penghargaan kelompok)

Penghargaan diberikan untuk kelompok dan bukan individu, sehingga keberhasilan kelompok ditentukan oleh keberhasilan setiap anggotanya. Penghargaan kelompok diberikan atas dasar rata-rata poin kelompok yang diperoleh dari game dan turnamen. Pendidik kemudian mengumumkan kelompok yang menang, masingmasing tim akan mendapat sertifikat atau hadiah apabila rata-rata skor memenuhi kriteria yang ditentukan. Team mendapat julukan sesuai poin yang diperoleh. Setelah mengikuti game dan turnamen, setiap kelompok akan memperoleh poin. Rata-rata poin kelompok yang diperoleh dari game dan turnamen akan digunakan sebagai penentu penghargaan kelompok. Jenis penghargaan sesuai dengan kriteria yang telah ditentukan. Penghargaan kelompok dapat berupa hadiah, sertifikat, dan sebagainya. 
Dapat dikatakan bahwa pembelajaran melalui teknik ini sama dengan STAD. Yang membedakannya adalah pada turnamen akademik pada TGT, menggunakan kuis-kuis dan sistem skor kemajuan individu dengan tujuan agar peserta didik berlomba sebagai wakil tim mereka dengan anggota tim lain yang kemampuan akademiknya setara. Tujuannya adalah supaya peserta didik yang prestasinya rendah pada setiap kelompok memiliki peluang yang sama untuk memperoleh poin bagi kelompoknya sebagai peserta didik yang punya prestasi tinggi. Meskipun keanggotaan kelompok tetap sama, tetapi peserta didik yang mewakili kelompok untuk bertanding dapat berubah-ubah atas dasar penampilan dan prestasi masingmasing anggota. Oleh karenya, mereka yang berprestasi rendah, yang pada awalnya berkompetisi dengan peserta didik yang kemampuannya sama dapat bertanding melawan yang berprestasi tinggi ketika mereka telah mampu.

\section{Hasil Penelitian}

Peneltian ini membahas tentang sikap mahasiswa semester III/C program studi Tadris Bahasa Inggris tahun akademik ganjil 2014/2015 STAIN Batusangkar terhadap penggunaan teknik Team Game Tournament (TGT) pada mata kuliah Reading Comprehension III. Yang menjadi responden penelitian ini adalah mahasiswa semester III/C program studi Tadris Bahasa Inggris STAIN Batusangkar yang berjumlah 38 orang.

Penelitian dilakukan seiring dengan perkuliahan sebagaimana biasanya. Yang berbeda dari pengajaran-pengajaran sebelumnyab adalah peneliti sebagai pengampu mata kuliah mencoba menggunakan teknik tersebut secara khusus kepada mahasiswa. Pelaksanaan penelitian dilakukan dengan melakukan permainan-permainan (games) dan diakhiri dengan kompetisi (tournament) sesuai dengan nama dan prosedur pelak- sanaan teknik tersebut. Pertemuan pertama dilaksanakan pada hari Rabu tanggal 8 Oktober 2014 jam 16.00 - 17.45 WIB. Pada hari tersebut permainan dirancang dengan memberikan bacaan dengan memberikan perintah menjawab pertanyaan sesuai dengan topik yang diajarkan hari itu. Pertemuan kedua dilaksanakan hari Sabtu tanggal 11 Oktober 2014 jam 08.00 - 09.45 WIB. Ini dilaksanakan bukan pada jadwal yang seharusnya, namun sudah disepakati bersama mahasiswa. Sewaktu aktivitas perkuliahan dengan menggunakan teknik tersebut berlansung, peneliti mencentang pilihan terhadap sikap setiap mahasiswa yang ada pada lembaran observasi (observation note). Ini dilakukan untuk melihat apakah mahasiswa-mahasiswa tersebut jujur dengan apa yang diisinya pada angket. Setelah semua materi terkait topik yang diajarkan selesai dibahas dan peneliti merasa benar-benar yakin mahasiswa akam mampu memahami apapun materi bacaan yang akan diberikan kepada mereka melalui teknik ini, maka peneliti selanjutnya melakukan kompetisi (tournament) kepada mereka. Ini dilaksanakan pada hari Selasa tanggal 28 Oktober 2014 jam 14.00 WIB. Setelah kompetisi dilakukan, peneliti meminta mahasiswa tersebut (responden penelitian ini) untuk mengisi angket penelitian. Ini peneliti lakukan karena peneliti beranggapan akan lebih baik memberikan angket tersebut sesegera mungkin agar mereka tidak sulit mengingat apa yang telah mereka rasakan dengan digunakannya teknik Team Game Tournament (TGT) tersebut.

Adapun angket tersebut dirancang dari variabel sikap menjadi indikator dan sub-indikator berdasarkan teori ahli tentang sikap. Peneliti melakukan validasi angket kepada salah seorang dosen senior terlebih dahulu sebelum diberikan kepada responden. Reevisi angket dilakukan beberapa kali. Setelah angket valid, baru angket diberikan kepada 
responden. Setelah pengisian angket selesai, kemudian peneliti mengumpulkan angket tersebut untuk diolah dengan merujuk pada langkah-langkah penelitian.

Sebelum data dianalisis, peneliti meminta responden untuk memilih pernyataan-pernyataan yang ada diangket yang paling cocok menurut pendapat mereka. Adapun total pernyataan berjumlah 30 pernyataan: 15 pernyataan positif dan 15 pernyataan negatif. Angket tersebut dirancang dengan menggunakan skala Likert yang sudah dibahas pada bab sebelumnya. Dari kalkulasi data, diperoleh data kuantitatif seperti yang terlihat pada tabel berikut ini.

Tabel 5.

\section{Skor Sikap Mahasiswa terhadap Penggunaan Teknik Team Game Tournament} (TGT) pada Mata Kuliah Reading Comprehension III

\begin{tabular}{cccc}
\hline Res & Skor & Res & Skor \\
\hline $\mathbf{1}$ & 120 & $\mathbf{2 0}$ & 123 \\
\hline $\mathbf{2}$ & 126 & $\mathbf{2 1}$ & 105 \\
\hline $\mathbf{3}$ & 114 & $\mathbf{2 2}$ & 132 \\
\hline $\mathbf{5}$ & 117 & $\mathbf{2 3}$ & 133 \\
\hline $\mathbf{6}$ & 117 & $\mathbf{2 4}$ & 123 \\
\hline $\mathbf{7}$ & 126 & $\mathbf{2 5}$ & 126 \\
\hline $\mathbf{8}$ & 118 & $\mathbf{2 6}$ & 122 \\
\hline $\mathbf{9}$ & 135 & $\mathbf{2 7}$ & 117 \\
\hline $\mathbf{1 0}$ & 112 & $\mathbf{2 8}$ & 121 \\
\hline $\mathbf{1 1}$ & 115 & $\mathbf{2 9}$ & 116 \\
\hline $\mathbf{1 2}$ & 127 & $\mathbf{3 0}$ & 132 \\
\hline $\mathbf{1 3}$ & 114 & $\mathbf{3 1}$ & 131 \\
\hline $\mathbf{1 4}$ & 122 & $\mathbf{3 2}$ & 130 \\
\hline $\mathbf{1 5}$ & 131 & $\mathbf{3 3}$ & 129 \\
\hline $\mathbf{1 6}$ & 118 & $\mathbf{3 4}$ & 144 \\
\hline $\mathbf{1 7}$ & 129 & $\mathbf{3 5}$ & 144 \\
\hline $\mathbf{1 8}$ & 122 & $\mathbf{3 6}$ & 132 \\
\hline $\mathbf{1 9}$ & 132 & $\mathbf{3 7}$ & 121 \\
\hline Total & 134 & $\mathbf{3 8}$ & 140 \\
\hline Mean & & & $\mathbf{4 7 5 0}$ \\
\hline Standar Deviasi & & & $\mathbf{1 2 5}$ \\
\hline Skor Minimum & & $\mathbf{8 , 8 5}$ \\
\hline Skor Maksimum & & $\mathbf{1 0 5}$ \\
\hline
\end{tabular}

Berdasarkan tabel diatas dapat dilihat bahwa skor sikap mahasiswa semester III/C program studi Tadris Bahasa Inggris tahun akademik ganjil 2014/2015 STAIN Batusangkar terhadap penggunaan teknik Team Game Tournament (TGT) pada mata kuliah Reading Comprehension III dengan skor tertinggi 144 dan yang terendah 105 . Total skor adalah 4750 dengan nilai ratarata 125. Adapun standar deviasi adalah 8,85 .

Selanjutnya peneliti mengelompokkan sikap mahasiswa tersebut. Dari pengkalkulasian diperoleh hasil sebagai berikut. 
Tabel 6.

Pengelompokkan Sikap Mahasiswa terhadap Penggunaan Teknik Team Game Tournament (TGT) pada Mata Kuliah Reading Comprehension III

\begin{tabular}{ccccc}
\hline No & Kelas Interval & Category & $\boldsymbol{F}$ & \% \\
\hline 1 & $\geq 138$ & Sangat Positif & 3 & 7,9 \\
\hline 2 & $129-138$ & Positif & 12 & 31,6 \\
\hline 3 & $120-129$ & Biasa-Biasa Saja & 12 & 31,6 \\
\hline 4 & $111-120$ & Negatif & 10 & 26,3 \\
\hline 5 & $<111$ & Sangat Negatif & 1 & 2,6 \\
\hline \multicolumn{7}{c}{ Jumlah } & 38 & 100 \\
\hline
\end{tabular}

Berdasarkan tabel diatas, peneliti mendapatkan 12 mahasiswa $(31,6 \%)$ memiliki sikap positif terhadap penggunaan teknik tersebut. Ada 12 mahasiswa $(31,6 \%)$ bersikap biasabiasa saja terhadap penggunaan teknik tersebut. Ada 10 mahasiswa $(26,3 \%)$ bersikap negatif terhadap penggunaan teknik tersebut. Ada 3 mahasiswa $(7,9 \%)$ bersikap sangat positif terhadap penggunaan teknik tersebut. Dan, ada 1 mahasiswa $(2,6 \%)$ bersikap sangat negatif terhadap penggunaan teknik tersebut.

Untuk mengetahui sikap mahasiswa tersebut terhadap penggunaan teknik ini, maka peneliti juga melihat bagaimana sikap mereka berdasarkan indikator sikap menurut teori yang dikutip. Dari kalkulasi data, didapatkan hasil yang dapat dilihat pada tabel

ini.

Tabel 7.

Sikap tentang Teknik Team Game Tournament Dapat Memberikan Banyak Peluang dalam Mengatasi dan Menyelesaikan Permasalahan Membaca

\begin{tabular}{ccccc}
\hline No & Kelas Interval & Category & $\boldsymbol{F}$ & $\boldsymbol{\%}$ \\
\hline 1 & $\geq 16$ & Sangat Positif & 3 & 7,9 \\
\hline 2 & $14-16$ & Positif & 16 & 42,1 \\
\hline 3 & $13-14$ & Biasa-Biasa Saja & 5 & 13,2 \\
\hline 4 & $11-13$ & Negatif & 14 & 36,8 \\
\hline 5 & $<11$ & Sangat Negatif & 0 & 0 \\
\hline \multicolumn{7}{r}{ Jumlah } & & 38 & 100 \\
\hline
\end{tabular}

Berdasarkan tabel diatas, peneliti mendapatkan 16 mahasiswa $(42,1 \%)$ memiliki sikap positif terhadap penggunaan teknik tersebut. Ada 14 mahasiswa $(36,8 \%)$ bersikap negatif terhadap penggunaan teknik tersebut. Ada 5 mahasiswa $(13,2 \%)$ bersikap biasa-biasa saja terhadap penggunaan teknik tersebut. Ada 3 mahasiswa $(7,9 \%)$ bersikap sangat positif terhadap penggunaan teknik tersebut. Dan, tidak ada mahasiswa (0\%) yang bersikap sangat negatif terhadap penggunaan teknik tersebut. 
Tabel 8.

Sikap Mahasiswa tentang Teknik Team Game Tournament mampu Membuat Mahasiswa Bekerja Sama, Memberi Rasa Aman dalam Mengatasi PersoalanPersoalan Membaca dan Membuat Lebih Memahami Isi Bacaan

\begin{tabular}{ccccc}
\hline No & Kelas Interval & Category & $\boldsymbol{F}$ & \% \\
\hline 1 & $\geq 29$ & Sangat Positif & 4 & 10,5 \\
\hline 2 & $27-29$ & Positif & 15 & 39,5 \\
\hline 3 & $25-27$ & Biasa-Biasa Saja & 9 & 23,7 \\
\hline 4 & $22-25$ & Negatif & 9 & 23,7 \\
\hline 5 & $<22$ & Sangat Negatif & 1 & 2,6 \\
\hline \multicolumn{7}{r}{ Jumlah } & & 38 & 100 \\
\hline
\end{tabular}

Berdasarkan tabel diatas, peneliti mendapatkan 15 mahasiswa $(39,5 \%)$ memiliki sikap positif terhadap penggunaan teknik tersebut. Ada 9 mahasiswa $(23,7 \%)$ bersikap biasabiasa saja terhadap penggunaan teknik tersebut. Ada 9 mahasiswa $(23,7 \%)$ bersikap negatif terhadap penggunaan teknik tersebut. Ada 4 mahasiswa $(10,5 \%)$ bersikap sangat positif terhadap penggunaan teknik tersebut. Dan, ada 1 mahasiswa $(2,6 \%)$ yang bersikap sangat negatif terhadap penggunaan teknik tersebut.

Tabel 9.

Sikap Mahasiswa tentang Teknik Team Game Tournament Mampu Membuat Mahasiswa Lebih Peduli Terhadap Mahasiswa Lainnya dalam Mengatasi Masalah-Masalah Membaca

\begin{tabular}{ccccc}
\hline No & Kelas Interval & Category & $\boldsymbol{F}$ & \% \\
\hline 1 & $\geq 10$ & Sangat Positif & 4 & 10,5 \\
\hline 2 & $9-10$ & Positif & 16 & 42,1 \\
\hline 3 & $8-9$ & Biasa-Biasa Saja & 10 & 26,3 \\
\hline 4 & $7-8$ & Negatif & 6 & 15,8 \\
\hline 5 & $<7$ & Sangat Negatif & 2 & 5,3 \\
\hline \multicolumn{7}{r}{ Jumlah } & & 38 & 100 \\
\hline
\end{tabular}

Berdasarkan tabel diatas, peneliti mendapatkan 16 mahasiswa $(42,1 \%)$ memiliki sikap positif terhadap penggunaan teknik tersebut. Ada 10 mahasiswa $(26,3 \%)$ bersikap biasa-biasa saja terhadap penggunaan teknik tersebut. Ada 6 mahasiswa $(15,8 \%)$ bersikap negatif terhadap penggunaan teknik tersebut. Ada 4 mahasiswa (10,5\%) bersikap sangat positif terhadap penggunaan teknik tersebut. Dan, ada 2 mahasiswa $(5,3 \%)$ yang bersikap sangat negatif terhadap penggunaan teknik tersebut. 
Tabel 10.

Sikap Mahasiswa tentang Teknik Team Game Tournament Mampu Membuat Mahasiswa Mau Bekerjasama dengan yang Lainnya dan Membuat Pelaksanaan Tugas Menjadi Lebih Menyenangkan

\begin{tabular}{ccccc}
\hline No & Kelas Interval & Category & $\boldsymbol{F}$ & $\boldsymbol{\%}$ \\
\hline 1 & $\geq 20$ & Sangat Positif & 9 & 23,7 \\
\hline 2 & $19-20$ & Positif & 4 & 10,5 \\
\hline 3 & $17-19$ & Biasa-Biasa Saja & 15 & 39,5 \\
\hline 4 & $15-17$ & Negatif & 9 & 23,7 \\
\hline 5 & $<15$ & Sangat Negatif & 1 & 2,6 \\
\hline \multicolumn{7}{r}{ Jumlah } & & 38 & 100 \\
\hline
\end{tabular}

Berdasarkan tabel diatas, peneliti mendapatkan 15 mahasiswa $(39,5 \%)$ memiliki sikap biasa-biasa saja terhadap penggunaan teknik tersebut. Ada 9 mahasiswa $(23,7 \%)$ bersikap sangat positif terhadap penggunaan teknik tersebut. Ada 9 mahasiswa
$(23,7 \%)$ bersikap negatif terhadap penggunaan teknik tersebut. Ada 4 mahasiswa $(10,5 \%)$ memiliki sikap positif terhadap penggunaan teknik tersebut. Dan, ada 1 mahasiswa $(2,6 \%)$ yang bersikap sangat negatif terhadap penggunaan teknik tersebut.

Tabel 11.

Sikap Mahasiswa tentang Teknik Team Game Tournament Mampu Membuat Lebih Bertanggung Jawab terhadap Tugas Mata Kuliah

\begin{tabular}{ccccc}
\hline No & Kelas Interval & Category & $\boldsymbol{F}$ & $\%$ \\
\hline 1 & $\geq 10$ & Sangat Positif & 8 & 21 \\
\hline 2 & $9-10$ & Positif & 16 & 42,1 \\
\hline 3 & $8-9$ & Biasa-Biasa Saja & 12 & 31,6 \\
\hline 4 & $7-8$ & Negatif & 2 & 5,3 \\
\hline 5 & $<7$ & Sangat Negatif & 0 & 0 \\
\hline \multicolumn{2}{r}{ Jumlah } & & 38 & 100 \\
\hline
\end{tabular}

Berdasarkan tabel diatas, peneliti mendapatkan 16 mahasiswa $(42,1 \%)$ memiliki sikap positif terhadap penggunaan teknik tersebut. Ada 12 mahasiswa $(31,6 \%)$ bersikap biasa-biasa saja terhadap penggunaan teknik tersebut. Ada 8 mahasiswa (21\%) bersikap sangat positif terhadap penggunaan teknik tersebut. Ada 2 mahasiswa $(5,3 \%)$ bersikap negatif terhadap penggunaan teknik tersebut. Dan, tidak ada mahasiswa (0\%) yang bersikap sangat negatif terhadap penggunaan teknik tersebut. 
Tabel 12.

Sikap Mahasiswa tentang Teknik Team Game Tournament Mampu Membuat Lebih Percaya Diri dalam Menyelesaikan Masalah Membaca

\begin{tabular}{ccccc}
\hline No & Kelas Interval & Category & $\boldsymbol{F}$ & \% \\
\hline 1 & $\geq 10$ & Sangat Positif & 5 & 13,2 \\
\hline 2 & $9-10$ & Positif & 14 & 36,8 \\
\hline 3 & $8-9$ & Biasa-Biasa Saja & 9 & 23,7 \\
\hline 4 & $7-8$ & Negatif & 9 & 23,7 \\
\hline No & Kelas Interval & Category & $F$ & $\%$ \\
\hline 5 & $<7$ & Sangat Negatif & 1 & 2,6 \\
\hline \multicolumn{2}{r}{ Jumlah } & & 38 & 100 \\
\hline
\end{tabular}

Berdasarkan tabel diatas, peneliti mendapatkan 14 mahasiswa $(36,8 \%)$ memiliki sikap positif terhadap penggunaan teknik tersebut. Ada 9 mahasiswa $(23,7 \%)$ bersikap biasa-biasa saja terhadap penggunaan teknik tersebut. Ada 9 mahasiswa $(23,7 \%)$ bersikap negatif terhadap penggunaan teknik tersebut. Ada 5 mahasiswa $(13,2 \%)$ bersikap sangat positif terhadap penggunaan teknik tersebut. Dan, ada 1 mahasiswa $(2,6 \%)$ yang bersikap sangat negatif terhadap penggunaan teknik tersebut.

Tabel 13.

Sikap Mahasiswa tentang Teknik Team Game Tournament Mampu Membuat Lebih Menghargai Kelebihan yang Dimiliki oleh Mahasiswa Lainnya

\begin{tabular}{ccccc}
\hline No & Kelas Interval & Category & $\boldsymbol{F}$ & \% \\
\hline 1 & $\geq 10$ & Sangat Positif & 7 & 18,4 \\
\hline 2 & $9-10$ & Positif & 16 & 42,1 \\
\hline 3 & $8-9$ & Biasa-Biasa Saja & 9 & 23,7 \\
\hline 4 & $6-8$ & Negatif & 4 & 10,5 \\
\hline 5 & $<6$ & Sangat Negatif & 2 & 5,3 \\
\hline & Jumlah & & 38 & 100 \\
\hline
\end{tabular}

Berdasarkan tabel diatas, peneliti mendapatkan 16 mahasiswa $(42,1 \%)$ memiliki sikap positif terhadap penggunaan teknik tersebut. Ada 9 mahasiswa $(23,7 \%)$ bersikap biasa-biasa saja terhadap penggunaan teknik tersebut. Ada 7 mahasiswa $(18,4 \%)$ bersikap sangat positif terhadap penggunaan teknik tersebut. Ada 4 mahasiswa (10,5\%) bersikap negatif terhadap penggunaan teknik tersebut. Dan, ada 2 mahasiswa $(5,3 \%)$ yang bersikap sangat negatif terhadap penggunaan teknik tersebut. 
Tabel 14.

Sikap Mahasiswa tentang Teknik Team Game Tournament Mampu Membuat Lebih Fokus dalam Pemecahan Masalah Membaca

\begin{tabular}{ccccc}
\hline No & Kelas Interval & Category & $\boldsymbol{F}$ & $\boldsymbol{\%}$ \\
\hline 1 & $\geq 10$ & Sangat Positif & 8 & 21 \\
\hline 2 & $9-10$ & Positif & 20 & 52,6 \\
\hline 3 & $8-9$ & Biasa-Biasa Saja & 5 & 13,2 \\
\hline 4 & $7-8$ & Negatif & 3 & 7,9 \\
\hline 5 & $<7$ & Sangat Negatif & 2 & 5,3 \\
\hline \multicolumn{2}{r}{ Jumlah } & & 38 & 100 \\
\hline
\end{tabular}

Berdasarkan tabel diatas, peneliti mendapatkan 20 mahasiswa $(52,6 \%)$ memiliki sikap positif terhadap penggunaan teknik tersebut. Ada 8 mahasiswa (21\%) bersikap sangat positif terhadap penggunaan teknik tersebut. Ada 5 mahasiswa $(13,2 \%)$ bersikap biasa-biasa saja terhadap penggunaan teknik tersebut. Ada 3 mahasiswa (7,9\%) bersikap negatif terhadap penggunaan teknik tersebut. Dan, ada 2 mahasiswa $(5,3 \%)$ yang bersikap sangat negatif terhadap penggunaan teknik tersebut.

Tabel 15.

Sikap Mahasiswa tentang Teknik Team Game Tournament Mampu Membuat Lebih Ingin Untuk Berbagi Pengetahuan dengan Mahasiswa Lainnya

\begin{tabular}{ccccc}
\hline No & Kelas Interval & Category & $\boldsymbol{F}$ & \% \\
\hline 1 & $\geq 10$ & Sangat Positif & 4 & 10,5 \\
\hline 2 & $9-10$ & Positif & 17 & 44,7 \\
\hline 3 & $8-9$ & Biasa-Biasa Saja & 8 & 21 \\
\hline 4 & $7-8$ & Negatif & 6 & 15,8 \\
\hline 5 & $<7$ & Sangat Negatif & 3 & 7,9 \\
\hline & Jumlah & & 38 & 100 \\
\hline
\end{tabular}

Berdasarkan tabel diatas, peneliti mendapatkan 17 mahasiswa $(44,7 \%)$ memiliki sikap positif terhadap penggunaan teknik tersebut. Ada 8 mahasiswa (21\%) bersikap biasa-biasa saja terhadap penggunaan teknik tersebut. Ada 6 mahasiswa $(15,8 \%)$ bersikap negatif terhadap penggunaan teknik tersebut. Ada 4 mahasiswa $(10,5 \%)$ bersikap sangat positif terhadap penggunaan teknik tersebut. Dan, ada 3 mahasiswa $(7,9 \%)$ yang bersikap sangat negatif terhadap penggunaan teknik tersebut.

Tabel 16.

Sikap Mahasiswa tentang Teknik Team Game Tournament Mengajarkan Mahasiswa Tidak Mudah Menyerah Ketika Mendapatkan Kendala dalam Membaca

\begin{tabular}{ccccc}
\hline No & Kelas Interval & Category & $\boldsymbol{F}$ & \% \\
\hline 1 & $\geq 10$ & Sangat Positif & 10 & 26,3 \\
\hline 2 & $9-10$ & Positif & 15 & 39,5 \\
\hline 3 & $8-9$ & Biasa-Biasa Saja & 6 & 15,8 \\
\hline 4 & $7-8$ & Negatif & 7 & 18,4 \\
\hline 5 & $<7$ & Sangat Negatif & 0 & 0 \\
\hline & & & 38 & 100 \\
\hline
\end{tabular}


Berdasarkan tabel diatas, peneliti mendapatkan 15 mahasiswa $(39,5 \%)$ memiliki sikap positif terhadap penggunaan teknik tersebut. Ada 10 mahasiswa $(26,3 \%)$ bersikap sangat positif terhadap penggunaan teknik tersebut. Ada 7 mahasiswa $(18,4 \%)$ bersikap negatif terhadap penggunaan teknik tersebut. Ada 6 mahasiswa $(15,8 \%)$ bersikap biasa-biasa saja terhadap penggunaan teknik tersebut. Dan, tidak ada mahasiswa $(0 \%)$ yang bersikap sangat negatif terhadap penggunaan teknik tersebut.

Tabel 17.

Sikap Mahasiswa tentang Teknik Team Game Tournament Membuat Lebih Bertanggung Jawab Terhadap Mahasiswa Lainnya di Dalam Kelas

\begin{tabular}{ccccc}
\hline No & Kelas Interval & Category & $\boldsymbol{F}$ & $\boldsymbol{\%}$ \\
\hline 1 & $\geq 10$ & Sangat Positif & 4 & 10,5 \\
\hline 2 & $9-10$ & Positif & 8 & 21 \\
\hline 3 & $7-9$ & Biasa-Biasa Saja & 21 & 55,3 \\
\hline 4 & $6-7$ & Negatif & 5 & 13,2 \\
\hline 5 & $<6$ & Sangat Negatif & 0 & 0 \\
\hline \multicolumn{2}{r}{ Jumlah } & & 38 & 100 \\
\hline
\end{tabular}

Berdasarkan tabel diatas, peneliti mendapatkan 21 mahasiswa $(55,3 \%)$ bersikap biasa-biasa saja terhadap penggunaan teknik tersebut. Ada 8 mahasiswa $(21 \%)$ memiliki sikap positif terhadap penggunaan teknik tersebut. Ada 5 mahasiswa $(13,2 \%)$ bersikap negatif terhadap penggunaan teknik tersebut. Ada 4 mahasiswa $(10,5 \%)$ bersikap sangat positif terhadap penggunaan teknik tersebut. Dan, tidak ada mahasiswa $(0 \%)$ yang bersikap sangat negatif terhadap penggunaan teknik tersebut.

Dari uraian di atas dapat diketahui setelah data dianalisa, peneliti mendapatkan 16 mahasiswa $(42,1 \%)$ memiliki sikap positif terhadap penggunaan teknik tersebut. Ada 14 mahasiswa $(36,8 \%)$ bersikap negatif terhadap penggunaan teknik tersebut. Ada 5 mahasiswa $(13,2 \%)$ bersikap biasa-biasa saja terhadap penggunaan teknik tersebut. Ada 3 mahasiswa $(7,9 \%)$ bersikap sangat positif terhadap penggunaan teknik tersebut. Dan, tidak ada mahasiswa (0\%) yang bersikap sangat negatif terhadap penggunaan teknik tersebut.
Mahasiswa yang memiliki sikap positif terhadap penggunaan teknik tersebut dipengaruhi oleh beberapa faktor. Salah satunya adalah pengalaman. Ini sejalan dengan teori Alex (2003: 355) yang mengatakan: "there are some factors that influence one's attitude. One of them is experience." Maka dapat dikatakan bahwa sebuah interaksi akan muncul jika seseorang memiliki kesamaan sikap terhadap sesuatu. Sebaliknya, seseorang akan bersikap negatif jika ia mengalami sesuatu yang sifatnya tidak menyenangkan baginya.

\section{PENUTUP}

\section{Kesimpulan}

Berdasarkan deskripsi dan analisis data, peneliti secara umum dapat menarik kesimpulan bahwa sikap mahasiswa semester III/C TA. Ganjil 2014/2015 program studi Tadris Bahasa Inggris Jurusan Tarbiyah STAIN Batusangkar terhadap penggunaan teknik Team Game Tournament (TGT) pada mata kuliah Reading Comprehension III adalah positif. Ini didapatkan dari skor 
angket yang diberikan kepada mahasiswa tersebut. Kalkulasi data menunjukan bahwa ada 16 mahasiswa $(42,1 \%)$ memiliki sikap positif terhadap penggunaan teknik tersebut.

Data yang lebih rincinya adalah sebagai berikut. ada 16 mahasiswa $(42,1 \%)$ memiliki sikap positif terhadap penggunaan teknik tersebut. Ada 14 mahasiswa $(36,8 \%)$ bersikap negatif terhadap penggunaan teknik tersebut. Ada 5 mahasiswa $(13,2 \%)$ bersikap biasabiasa saja terhadap penggunaan teknik tersebut. Ada 3 mahasiswa (7,9\%) bersikap sangat positif terhadap penggunaan teknik tersebut. Dan, tidak ada mahasiswa $(0 \%)$ yang bersikap sangat

\section{DAFTAR RUJUKAN}

Alex Sobur. 2003. Psikologi Umum. Bandung: Pustaka Setia.

Anas Sudijono. 2005. Pengantar Statistik Pendidikan. Jakarta: Raja Grafindo Prakarsa.

Bimo Walgito. 2003. Pengantar Psikologi Umum. Yogyakarta: Andi Offset.

Dise Sriyanti. 2012. Students' Attitude toward Instructional Media Used by Their English Teacher (A Study of the Students of MAS Padang Ganting Registered in 2012/2013 Academic Year). (Unpublished Thesis). Batusangkar: STAIN Batusangkar Press.

Djaali. 2007. Psikologi Pendidikan. Jakarta: Bumi Aksara.

Fieldman, Robert. 1996. Understanding of Psychology (Fourth Edition). New York: Mc. Grow Hill Company.

Gay, L.P. 2000. Educational Research. Columbus: Merril Publishing Company. negatif terhadap penggunaan teknik tersebut.

\section{Saran}

Berdasarkan hasil penelitian, peneliti ingin menyampaikan saran kepada dosen pengampu mata kuliah Reading Comprehension, termasuk peneliti sendiri untuk dapat menggunakan teknik Team Game Tournament (TGT) ini didalam pengajaran Reading. Selanjutnya, kepada mahasiswa yang mengambil mata kuliah Reading Comprehension III agar dapat meningkatkan sikap mereka terhadap teknik ini karena telah terbukti dapat meningkatkan minat membaca mereka.

Harmer, Jeremy. 2003. The Principles of English Language Teaching. London: Longman.

Hendra. 2012. Students' Attitude toward Group Work Technique (A Study of the Second Semester Students of English Department of STAIN Batusangkar in 2010/2011 Academic Year). (Unpublished Thesis). Batusangkar: STAIN Batusangkar Press.

Hollander, Edwin. 1981. Principles and Method of Social Psychology (Fourth Edition). Oxford: Oxford University Press.

Muhibbin Syah. 2007. Psikologi Pendidikan dengan Pendekatan Baru. Bandung: PT. Remaja Rosdakarya.

Ngalim Purwanto. 2007. Psikologi Pendidikan. Bandung: PT. Remaja Rosdakarya.

Purwanto. 2004. Evaluasi Hasil Belajar. Yogyakarta: Pustaka Belajar.

Ogi Putra. 2014. Students' Attitude toward Assignment Given by the Lecturer of Speaking IV Subject 
(A Study of the Fifth Semester Students of English Department of STAIN Batusangkar in 2013/2014 Academic Year). (Unpublished Thesis). Batusangkar: STAIN Batusangkar Press.

Sarlito Wirawan Sarwono. 2010. Pengantar Psikologi Umum. Jakarta: Pers.

Slavin, Robert E. 2008. Cooperative Learning. Bandung: Nusa Media.

Suharsimi Arikunto. 1996. Dasar-Dasar Evaluasi Pendidikan. Jakarta: Bumi Akasara.
Teed, Rebecca. 2013. Cooperative Learning. Adapted from: http://www4.ncsu.edu/unity/locker s/users/f/felder/public/Papers/CLC hapter.doc-CLChapter.pdf. Retrieved on March 1, 2013

Wikipedia. 2013. Cooperative Learning. Adapted from: http://en.wikipedia,org/wiki/cooper ativelearning. Retrieved on February_15, 2013. 